\title{
Enhancing the Resilience of Human-Environment Systems: a Social Ecological Perspective
}

\author{
Daniel Stokols $^{1}$, Raul Perez Lejano $^{1}$ and $\underline{\text { John Hipp }}^{1}$
}

\begin{abstract}
Resilience studies build on the notion that phenomena in the real world should be understood as dynamic socialecological systems. However, the scholarly community may not be fully aware that social ecology, as a conceptual framework, has a long intellectual history, nor fully cognizant of its foundational theory. In this article, we trace the intellectual roots and core principles of social ecology and demonstrate how these principles enable a broader conceptualization of resilience than may be found in much of the literature. We then illustrate how the resulting notion of resilience as transactional process and multi-capital formation affords new perspectives on diverse phenomena such as global financial crises and adaptation to environmental stresses to communities and ecosystems. A social-ecological analysis of resilience enables the study of peopleenvironment transactions across varying dimensions, time periods, and scales. Furthermore, in its openness to experiential knowledge and action research, the social ecology framework coheres well with participative-collaborative modes of inquiry, which traverse institutional, epistemological, and scale-related boundaries.
\end{abstract}

Key Words: environment-behavior transactions; resilience; social capital; social ecology

\section{INTRODUCTION}

The first decade of the 21st Century has witnessed a succession of turbulent and disruptive developments at geologic, climatic, and sociopolitical levels-from extreme weather events such as epochal hurricanes and floods, geologic disruptions epitomized by the Indian Ocean and Sendai earthquakes and tsunamis, to the 9/11 terror attacks, ongoing wars in Iraq and Afghanistan, ethnic genocide in Darfur, popular uprisings in several Arab countries during 2011, and the global economic recession of 2008 (Stokols et al. 2009). Reflecting on the succession of calamitous events that have occurred in recent years, scholars and policy makers alike have begun questioning whether humans' capacity for protecting the nearterm resilience and longer-term sustainability of the earth's fragile ecosystems has been inexorably surpassed by these converging environmental and societal perturbations (Gunderson and Folke 2011, Schoon et al. 2011).

Owing to the enormous complexities inherent in mapping the boundaries, energy flows, and cumulative outcomes of human-environment systems at multiple scales, researchers from the behavioral and environmental sciences increasingly are embracing social-ecological models as a framework for conceptualizing and managing the resilience and sustainability of human-environment systems (Berkes et al. 2003, Folke 2006, Peterson 2010). An important reason for the prominence of social-ecological models in these discussions is that they emphasize certain core assumptions that enable broad-gauged analyses of the complex and dynamic interplay among biological, environmental, and sociopolitical components of human ecosystems, spanning multiple time intervals and local as well as global levels (cf., Stokols 1992, Redman et al. 2004, Ostrom 2009). Thus, the broad scope of social-ecological models and their emphasis on key assumptions and methods drawn from complex systems theory are well suited for analyzing human resilience and sustainability during an era marked by profound environmental and societal disruptions (von Bertalanffy 1950, Maruyama 1963, Emery 1969).

Although we share this general interest in integrated socialecological models, we also draw from a particular conceptual framework, known as the social ecology paradigm, that resilience scholars may not be aware of. Within this particular framework, scholars of social ecology have generated a set of epistemological and methodological propositions that have a different emphasis than (and, in some aspects, depart from) what the resilience literature means by the term, social ecology. It is our conviction that resilience research can be enhanced by a deeper appreciation of this long-historied yet evolving conceptual framework.

In this article, we briefly trace the emergence and core themes of social ecology as a basis for understanding and enhancing the quality of people-environment relationships. First, the social-ecological paradigm involves an appreciation of how persons, groups, and other actors subsist in and through transactional relationships among interacting natural and semiotic systems. Rather than view the material and semiotic as independent or even dialectically opposed systems, the social-ecological perspective has a primary focus on the continuous exchanges that occur between these systems. These exchanges, which we refer to as transactions, are bidirectional and mutually influencing. Second, the socialecological framework attempts to address the close interdependence of the natural and semiotic worlds and the challenges that their conjunction poses for the modeler. 
Whether a system is in dynamic equilibrium or ever-changing panarchy, the most conventional mode of viewing the system is modeling the state space in material-thermodynamic terms. But how do we model such a system when part of the state space exists in the semiotic domain-i.e., the world of meaning? We encounter phenomena that are not only crossscale in nature, but cross-dimensional (or in other words, crossontological). In the next section, we discuss some of the conceptual and analytical directions we take to deal with this challenge.

We also demonstrate how the deliberate application of socialecological principles to the analysis of human-environment transactions can yield rich new insights into the meaning of resilience. We take as a starting point the definition of resilience proposed by Walker et al. (2004) as “...the capacity of a system to absorb disturbance and reorganize while undergoing change so as to still retain essentially the same function, structure, identity, and feedbacks." Maintaining resilience through adaptability is an important prerequisite for ensuring the longer-term sustainability of a humanenvironment system.

A daunting challenge facing analyses of resilience and sustainability as dynamic features of social-ecological systems is that these constructs are sometimes construed so broadly and generically that they result in rather diffuse, nonspecific characterizations of people-environment relationships. As such, they may fail to provide a useful basis for creating social and environmental interventions aimed at enhancing the overall quality and viability of a particular system. In the following sections, we propose certain analytic strategies that render social-ecological analyses of resilience and sustainability more targeted and strategic.

\section{HISTORY: THE EMERGENCE OF SOCIAL ECOLOGY AS A CONCEPTUAL FRAMEWORK FOR UNDERSTANDING HUMAN-ENVIRONMENT TRANSACTIONS}

The term, ecology, refers to the study of the interrelationships between organisms and their environments. Ecological analyses of organism-environment relationships originated among evolutionary biologists engaged in naturalistic observations of biomes-i.e., geographically bounded areas populated by both animal and plant species. These scholars (e.g., Darwin 1859/1964, Haeckel and Lankaster 1876, Clements 1905) were particularly interested in elucidating the processes of adaptation and natural selection by which the biotic components of a biome (i.e., resident plant and animal species) achieve dynamic equilibrium with its abiotic elements (e.g., climate, hydration, geologic conditions).

The conceptual and methodological tools developed by bioecologists during the 19th Century (especially naturalistic, longitudinal observations of plant and animal habitats highlighting homeostatic processes of adaptation) were later applied to the study of human communities, or ecosystems, by a group of sociologists at the University of Chicago during the 1920s and 1930s. This group came to be known as the Chicago School of Human Ecology (Park et al. 1925) and was broadened to include like-minded sociologists based at other universities (e.g., Hawley 1950). The Chicago School combined the bioecologists' emphasis on adaptation processes with macro economic theories of urban development (e.g., Haig's (1926) theory of highest and best use of land and Christaller's (1933) central place theory) to explain the spatial distribution of financial resources, behavioral disorders, and health problems observed among sub-groups of Chicago's population residing in different zones of the metropolitan region.

However, the relationships between material and social dimensions of urban communities, as construed by the Chicago School human ecologists, emphasized the unidirectional influence of material conditions on social phenomena, rather than the reciprocal transactions among them. An additional limitation of the Chicago School's "concentric zone" theory of human ecology is that it overemphasized biological and economic facets of human ecosystems while neglecting the sociopolitical, symbolic, legal, philosophical, ethical, and environmental design facets of human communities (cf., Michelson 1970). In his landmark article on "Sentiment and symbolism as ecological variables," Firey (1945) contended that environmental elements of human ecosystems convey symbolic as well as material meanings that often exist independently from or in contrast to their economic and locational values. Similarly, Alihan (1938) had published an earlier critique of the Chicago School calling for the establishment of a more integrative interdisciplinary conceptualization of human communities that combined the concerns of bioecology and economics with those of ethics, anthropology, urban planning, psychology, sociology, and other fields.

Alihan and systems theorists such as Emery and Trist (1972) writing after her, referred to this broader conceptualization and study of human-environment relationships as social ecology. This more integrative vision of human ecosystems gradually took institutional form, as university-based training programs in social ecology were established at the University of Vermont and the University of California, Irvine (Binder 1972, Bookchin 2005). Bronfenbrenner's (1979, 1992) ecology of human development research conducted at Cornell University similarly reflected a broad-gauged conception of human-environment transactions spanning micro, meso, and macro-societal levels of analysis and helped shape the research directions and conceptual orientation of Cornell's College of Human Ecology. Other institutional initiatives have since taken root, e.g., the Social Ecology Program at Yale University's School of Forestry and Environmental Studies, the Program in Social Ecology at the University of Western 
Sydney, the Institute of Social Ecology at Klagenfurt University, Vienna, and the Institute for Social Ecological Research in Frankfurt, Germany. In contemporary scholarship, social ecology generally refers to the study of communities from a broad, interdisciplinary perspective that encompasses bioecological and macro-economic concerns, but gives greater attention to the social, psychological, institutional, and cultural contexts of people-environment relationships than did earlier human ecology research (Michelson 1970, Moos 1979, Stokols 1996, Redman 1999, Stokols et al. 2003, Ostrom 2009, Peterson 2010).

Thus, the emergent notion of social ecology was founded on a realization of the limitations of understanding societal problems wholly in material/ecological terms, an insight stemming in part from early phenomenological work on the difference between natural and semiotic worlds (cf., Husserl 1900). Phenomena in the symbolic/semiotic plane may behave according to altogether different logics from those in the material plane. Take, for example, the notion of natural selection in the material plane which, if translated into notions of "social Darwinism," violate deep ethical norms and run counter to contemporary concerns about environmental justice (cf., Bullard 2005). Within the social-ecological framework, what Aristotle referred to as formal causes, which operate in the symbolic plane of phenomena, are as important as the efficient causes, which operate in the material plane (Altman and Rogoff 1987).

\section{CORE PRINCIPLES OF SOCIAL ECOLOGY}

Our conceptualization of resilience in human-environment systems incorporates a number of core principles or themes emphasized in contemporary social-ecological research:

First, social ecology highlights the multidimensional structure of human environments. Environmental settings can be characterized in terms of their physical and social components; natural and built (or designed) features; objective (material, observable) as well as subjective (perceived, semiotic) qualities; and their scale or immediacy to individuals and groups (proximal vs. distal). Moreover, the participants in environments include individuals, small groups, and organizations that also comprise larger communities and populations.

Second, social-ecological analyses incorporate multiple levels of analysis and diverse methodologies for assessing the resilience and healthfulness of settings and the well-being of individuals and groups. This contextual, multi-level perspective construes human environments as complex systems in which local settings and organizations are nested within more complex and remote regions. Thus, efforts to understand and enhance the resilience of particular humanenvironment systems must take into account the interdependencies that exist among immediate and more distant environments (cf., Stokols et al. 2009).
Third, social ecology draws upon key concepts and assumptions derived from systems theory, such as interdependence, homeostasis, negative feedback, and deviation amplification, to understand the interrelationships among people and their surroundings (Maruyama 1963, Katz and Kahn 1966, Emery 1969). Systems analyses suggest that the resilience of particular settings and the well-being of their participants are jointly influenced by multiple facets of the physical environment (e.g., geography, architecture, technology) and the social environment (e.g., culture, ethics, economics, politics, law). The resilience and healthfulness of these settings is also influenced by the attributes of individual members including their genetic heritage, cognition, and behavior. From the vantage point of ecological systems theory, efforts to promote organizational or community resilience should be based on an understanding of the dynamic reciprocal transactions that occur among diverse environmental and personal factors, rather than on analyses that focus more narrowly on specific environmental, biological, or behavioral causal factors. These cycles of mutual influence are relationships that are both structuring and agentic, wherein people not only are acted upon by their environment or merely reproduce larger sociocultural constructs, but plan-fully act to modify these as well (Giddens 1984).

Fourth, social-ecological analyses of human-environment systems emphasize a transdisciplinary action research orientation in which diverse knowledge cultures or epistemologies (e.g., academic-disciplinary, professionalpractitioner, lay citizen perspectives) are brought together for purposes of better understanding and ultimately improving the resilience and sustainability of people-environment systems (cf., Stokols 2006, Brown 2010).

How does our understanding of the social-ecological compare with that implicit in much of the resilience scholarship? In the broadest sense, we understand it in exactly the same waythat is, as the interactive dimensions of the material and the sociocultural (e.g., Berkes and Folke 1998, Anderies et al. 2004). But in the framework presented herein, there is a distinctly greater emphasis on some social-symbolic aspects of complex systems, which has implications for analytic method. Perhaps some of this shift in emphasis stems from the fact that, as many of us are grounded in the social sciences, we began in the dimension of the sociocultural (i.e., the semiotic world of meaning) and moved to incorporate the natural dimension, whereas ecologists may approach it from the other direction. The shared desire to capture both natural and semiotic systems leads to many possible analytic strategies. Biodynamic models capture the natural system, then overlay on top of that economic decision routines that drive how these natural systems are managed (e.g., Smith et al. 2008). A related strategy is an institutional one, where rules and systems of property rights include non-economic considerations as well (e.g., Anderies et al. 2004). Both capture 
Table 1. Forms of capital

\section{Material Resources}

Economic/financial capital:

Natural capital:

Human-made environmental capital:

Technological capital:

\section{Human Resources}

Social capital:

Human capital:

Moral capital:
Financial assets for enhancing productivity

Resources produced through natural processes

Physical resources designed and built by humans

Machinery, equipment, digital/communication devices

Relationships among people that facilitate action

Capacities of persons, including skills and information

Investment of personal and collective resources toward justice/virtue the material-semiotic relationship in a more structural, objectified way-i.e., as feedback loops between one and the other. In our treatment of the social ecological, we endeavor to more explicitly depict the transactions across ontological dimensions, including that of meaning, which may be shared but non-objectified.

One strategy we employ is to model these different dimensions as distinct but, to some extent, interrelated types of resources. The social-ecological system, then, is one of interacting stores of natural, social, and other types of capital. And this then leads us to more closely study the mode by which one resource is transformed into another.

We note, however, that although we observe transactions between different forms of capital, they are by no means considered interchangeable (Neumayer 1999). Whereas social capital is, in some ways, transformable to economic capital, this does not mean that they are fungible in a measurable sense - so being, social capital is described in different ways than financial capital.

There are analytical implications of our commitment to fully account for the semiotic dimension. One important consequence is our emphasis on the contextuality of socialecological phenomena. The same environmental data can have very dissimilar meanings to different communities. As anecdotal evidence of this, simply imagine the very different reactions people of divergent ideological-political allegiances display when shown a chart of carbon dioxide measurements over time from the Mauna Loa observatory. Examples of context-centered research include efforts to understand how communities interpret the idea of "neighborhood" and its implications for community life (Hipp et al. 2011), how place attachment affects environmental behavior (Ogunseitan 2005), or how participatory action research complements technical knowledge (e.g., González et al. 2007). By being open to the everyday experience of subjects, the socialecological frame coheres well with action-research as a mode of participative-collaborative inquiry. Our commitment to the dimension of meaning also moves us to explore ways of "modeling" systems by incorporating the natural into models that are hitherto semiotic. An example of the latter strategy is found in attempts to capture social-ecological systems on the plane of narrative (e.g., Lejano and Leong 2012).

Thus, social ecology emphasizes processes involving transactions among multiple and ontologically diverse assets, resources, and actors. Close attention is paid to the relationships among what Bourdieu referred to as multiple forms of capital (Bourdieu 1977, 1986). In Bourdieu's framework, the term "capital" refers to any resource or asset that social actors can employ to further their goals. Social capital, for example, can be understood as a personal asset residing in an individual's network of supportive relationships (Bourdieu 1986). Coleman (1988) draws a distinction between human and social capital: "...human capital is created by changes in persons that bring about skills and capabilities that make them able to act in new ways. Social capital, however, comes about through changes in the relations among persons that facilitate action" (see also Putnam 2000).

In Table 1, we illustrate different forms of assets that society can capitalize on in meeting its goals (cf., Stokols et al. 2003). These assets are grouped under two categories, material and human resources. The former includes economic capital, or material goods that facilitate the creation of new products and financial growth (cf., Marx 1930); natural capital or those resources produced through nature-based processes (e.g., geochemical, geothermal), as distinct from human-made environmental capital such as buildings, vehicles, tools, and other products created by people (cf., Costanza et al. 1997, Daily and Ehrlich 1999, Hawken et al. 1999); and technological capital, an important sub-category of humanmade environmental capital exemplified by telephone systems, computing and mobile communications equipment, and fiber optic technology (cf., Castells 1996). The second category of societal assets shown in Table 1 includes human capital created through changes in persons (e.g., educational experiences) that equip them with new skills and capabilities that enable them to act in new ways (Coleman 1988); social capital, or changes in the relationships among persons that facilitate their coordinated action for mutual benefit (Bourdieu 1986, Putnam 2000); and finally, moral capital, or the investment of personal and collective resources toward the 
Fig. 1. Schematic representations of human-environment transactions

\section{Resilient Environment-Behavior Systems}

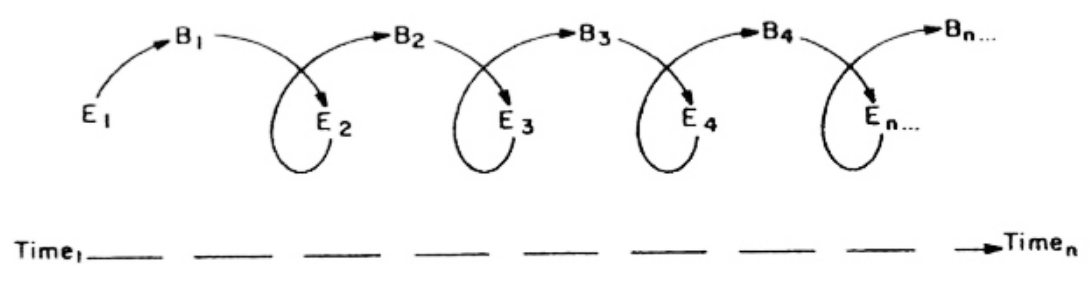

\section{Non-Resilient Environment-Behavior Systems}

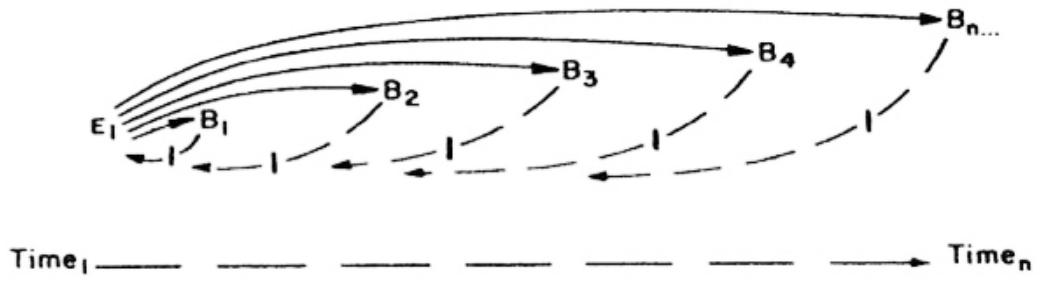

(adapted from Stokols, 1978)

cultivation of virtue and justice (cf., Rosenblum 1998, Berkowitz 1999, Miller 1999, Stokols et al. 2003).

Moral capital is a crucially important, yet often overlooked, societal asset. It is distinct from social capital in its basis on ethical grounds rather than social organization. For instance, the social capital that often exists among members of violent gangs is typically maintained at the expense of non-members in the community, who are victimized by their actions. Moral capital, on the other hand, can speak to collective norms that transcend intra-group social ties and inter-group differences. This type of value simply reflects the strength and positive attributes of "people's moral perceptions of political actors, causes, institutions and organisations" (Kane 2001: 4). High levels of moral capital within a community or society would be reflected, for example, in the existence of widely shared, consensual guidelines for mobilizing and distributing community resources (e.g., public policies that ensure access to high-quality health services among all members of the population, and those that mitigate or prevent instances of environmental injustice (cf., Bullard and Johnson 2000, Stokols et al. 2003). Moral capital would also be associated with a commonly held "faith" in social institutions and processes, without which, civic engagement (and activities like voting, payment of taxes, etc.) suffers. Societies lacking widely shared, ethical norms to guide the development and distribution of limited resources among their component groups are likely to be less resilient and effective in their responses to environmental perturbations and resource scarcities than those collectivities in which high levels of moral capital prevail.

Human capital refers to capabilities of individuals and groups and overlaps with Bourdieu's (1986) notion of cultural capital. Other forms of capital, shown in Figure 1, are more conventionally recognized as material and technological resources that people can use to enhance their well-being and surroundings. Examples A and B, below, will further clarify the meanings of these terms.

The proposed multifaceted conceptualization of capitalized assets has direct relevance for resilience theory, which highlights transactions wherein decrements in one form of capital (e.g., hazards from extreme weather events) are addressed through the mobilization of other forms of capital (e.g., social capital in terms of a network of emergency service providers; moral capital in the form of norms about sharing in times of need). An example of this can be found in Tidball and Krasny (2012), which describes how some communities inject care into hitherto dispossessed or disturbed environments through "greening." On the other hand, obstacles to such transactions can characterize non-resilient systems (Gunderson and Folke 2011, Schoon et al. 2011). In the following sections, we illustrate how these transactional processes are analyzed, and how the configuration of such transactions can result in higher or lower levels of system resilience. 


\section{DYNAMIC FEATURES OF RESILIENT AND NON- RESILIENT SYSTEMS}

The social ecology of resilience, proposed here, suggests new ways to understand resilience, while also being consistent with Walker et al.'s (2004) conceptualization. For example, one way to construe resilience from the vantage point of our own social-ecological perspective would entail an explicitly transactional, process-oriented definition, as follows:

Human-environment systems are characterized by mutually overlapping transactions wherein humans adjust to (i.e., situationally constraining or promotive) influences of the environment on the achievement of social goals, and in turn, attempt to modify the environment in furtherance of these same goals. Resilient systems are those wherein both processes of adaptation and modification exist that positively and mutually support these goals for the overall betterment of the collectivity, as a whole.

In the context of people's reciprocal transactions with their environments, their goal-oriented behavior may follow the logics of material, biological, or economic advantage, but also can be constructed according to more complex narratives (Lejano et al. 2013). Moreover, a transactional approach emphasizes the bidirectional nature of exchange between humans and their environments.

One strategy for representing the level of resilience in a system is to identify circumstances under which various kinds of people-environment transactions are mutually supportive (progressive) or mutually non-supportive (regressive) as depicted in Fig. 1. As a basis for extending earlier ecological analyses of resilience, we introduce the idea that resilient transactions in human-environment systems depend on the effective and strategic mobilization of different kinds of material and human resources for purposes of achieving and sustaining desirable states of the system. It is through effective mobilization or capitalization of these community assets that higher levels of adaptability, resilience, and longer-term sustainability can be achieved (Stokols et al. 2003). Key categories of material and human resources or capital are as previously listed in Table 1. Figure 1 emphasizes the transactional notion of human-environment interactions, and one might even see it as a more process-focused interpretation of the concept of panarchy proposed by Gunderson and Holling (2002).

In Fig. 1, we see sequences of environment-behavior (E-B) transactions wherein changes in environment can induce a variety of responses (be they individual, organizational, or societal). In resilient systems, environmental changes in an ecosystem prompt its members to make various kinds of changes in their sociophysical environment that are intended to enhance the level of congruence or fit between themselves and their surroundings (cf., Michelson 1970, Stokols 1978). In turn, these environmental modifications evoke subsequent behavioral changes aimed at achieving even higher levels of human-environment fit. These transactions entail more than simply overt, observable behavior and also include subjective understandings and perceptions of the situation. These reciprocal cycles of mutual influence between environments and the behavior result in a pattern of continually evolving and mutually adaptive transactions. This model also can apply to non-human organisms and objects as actors. This latter attribution of agency to non-human actors is quite possible in a social-ecological analytic framework; it is given great importance in some conceptual frameworks such as Latour's (2005) actor-network theory.

In contrast, less-resilient systems are depicted in the lower half of Fig. 1, in which physical or institutional environments are so rigidly constrained and unyielding that it becomes impossible for the actors in these systems to modify their surroundings in adaptive fashion. The inability to modify situational constraints in accord with personal or group goals is represented by the blocked, broken arrows leading from behavioral states at times $1-n$ toward the unyielding environmental conditions (E1). Thus, their behaviors remain captive to the dictates of a rigid environment, thereby precluding any mutually adaptive, reciprocal responses between environmental changes and corresponding human/ agent behaviors. In the discussion below, we illustrate these two contrasting patterns of environment-behavior transactions.

Our analysis further assumes that transactions involving certain kinds of capital, compared with others, may exert greater leverage toward either diminishing or bolstering the resilience of a system. Accordingly, it becomes essential to identify high-leverage points of intervention within complex, multi-level systems, as a basis for strengthening the resilience of an individual, organization, community, or society. By so doing, we are able to extend previous and less targeted socialecological models by focusing on the points of highest leverage in a system for enhancing its resilience; and perhaps, by also offering criteria or guidelines for characterizing the relative leverage or impact value associated with various system components.

\section{SPATIAL/TEMPORAL CONSIDERATIONS}

The social-ecological paradigm encompasses, as part of its focus on transaction, the ongoing exchanges among people and environments that occur across varying times and scales. It is important to consider both the temporal and spatial scale of the system under study. The temporal dimension is essential for understanding the level of resilience of a system. In some cases, a system may demonstrate short-term stability. However, the ways in which the system maintains equilibrium within a particular time frame may actually render the resilience of the system more fragile in the longer run. Of course, what actually constitutes "short-term" or "long-term" varies based on the particular system being studied. Thus, 
gauging the level of system resilience requires explicitly defining the time frame being considered, and considering whether higher levels of short-term resilience may actually result in lower levels of long-term resilience.

Similarly, defining the spatial scale of the system is crucial within the social-ecological approach. In some instances, subcomponents of the system may be more resilient than the larger whole. It may also be the case that the resilience of some systems requires the maintenance of only some sub-parts of the larger system. Conversely, in certain instances the resilience of smaller portions of the larger system can result in negative consequences for the entire system. In part, our notion of moral capital is meant to capture such circumstances. Nonetheless, it is useful to explicitly consider the spatial scale of the system under study.

These considerations also underscore the point that simultaneously considering the temporal and spatial scales is essential for understanding system resilience. The resilience of certain portions of the system, within certain time periods, may well differ from the resilience of the entire system over more extended temporal periods.

\section{Example A: Nonresilient Political Ecologies}

As an illustration of the points discussed above, the current financial recession and debt-ceiling debates can be viewed in terms of the dynamic interplay among various kinds of resources, including financial capital (currency values, stock prices, interest rates, GDP, national debt), ecological capital (e.g., protection and preservation of natural resources through environmental conservation strategies), technological capital (e.g., development of clean energy technologies; high volume purchases or sell-offs of corporate stocks that are triggered by rather rigid computer algorithms), social and human capital (increasing rates of income inequality and uneven access to educational and employment resources in U.S. society), human-made (vs. natural) environmental capital (e.g., establishment of an infrastructure development program in the USA to reduce unemployment), and finally moral capital or lack thereof (e.g., the unwillingness among many members of Congress to compromise in the interests of achieving balanced solutions to the U.S. debt problem and their corresponding zeal to crash the system by forcing the USA to default on its debt).

The example of the U.S. debt ceiling debates, which raged in Washington in the latter part of 2011, exemplify what Schoon et al. (2011) refer to as robustness-vulnerability tradeoffs and potentially devastating lock-in traps that often arise within non-resilient systems. It seems plausible to suggest that the disadvantageous tradeoffs favoring greater vulnerability (over robustness) and heightened potential for creating inescapable lock-in traps are occurring within the U.S. economic systems, and more broadly within the global economy, not because the U.S. government lacks the financial capital to invest in infrastructure development (environmental capital) or novel green energy technologies (technological and ecological capital), but rather because its politicians lack sufficient consensus and fortitude to take collective action (e.g., strategic investments of economic capital as an adjunct to cost-cutting measures) that would promote job growth, lower the national debt over the long run, while also reducing income inequality and strengthening social capital.

In this example, the greatest leverage for enhancing the resilience of the U.S. and global economies would be achieved by mobilizing human resources such as social and moral capital, such that opposing political factions are better able to accommodate to the concerns and needs of others they view as outsiders. Thus, the economic, environmental, technological, human, and social capital in our national system could be substantially enlarged through focused efforts to strengthen social and moral capital. A potential strategy for increasing coordinated action among factions that currently oppose each other may be to create situations or scenarios that raise the salience of shared, superordinate goals (Sherif 1958).

However, the United States' present financial system is characterized by perverse feedback mechanisms that lead to greater volatility (and, hence, decreased resilience). Consider how digital technologies, rather than compensating for decrements in financial capital, compound the problem. By enabling more rapid and larger-volume transactions, digital technology exacerbates the upswings and downswings in stock prices (Sweet 2011). In 2008, these automated (and in many respects, mindless) processes helped push the stock market beyond a tipping point, from which it has taken almost 3 years to recover. Consider also the ensuing political responses to these economic crises by members of the U.S. Congress, which rather than move toward a concerted effort at jobs creation or stimulus, has instead focused on fueling an ideological divide that has stalled bipartisan action.

A social-ecological perspective on resilience, as reflected in Fig. 1, would entail analyzing the different sequences of system change (E1), the suite of behavioral responses (B1, B2, etc.), and the resulting processes of system modification. This process-based understanding of resilience enables us to view these transactions as either leading to reduced volatility or exacerbating it. The notion of interlocking forms of capital also allows us to view whether different forms of capital counteract decrements in the resource or economic base. In the above case, the analysis might find perverse effects, where decrements in financial capital lead to a degradation of social and moral capital (as evidenced in budgetary and ideological gridlock)—exemplifying what Maruyama (1963) referred to as deviation amplifying processes in systems. 


\section{Example B: Resilient Adaptations to Environmental Stress}

In 1998, the County of Los Angeles decided to expand the Chiquita landfill, which is separated from the nearby community of Val Verde, Los Angeles, by a row of low-lying hills. The project's environmental impact statement (County of Los Angeles 1992, 1996) had identified less than significant environmental effects on the region and community. Nonetheless, this action initiated a series of responses, or transactions in our nomenclature, that we describe below for purposes of characterizing this system in social-ecological terms. Figure 2 outlines the analytical approach suggested by a social-ecological framework and depicts these transactions as exchanges among the interacting system of various forms of capital.

Fig. 2. Cross-dimensional transactions

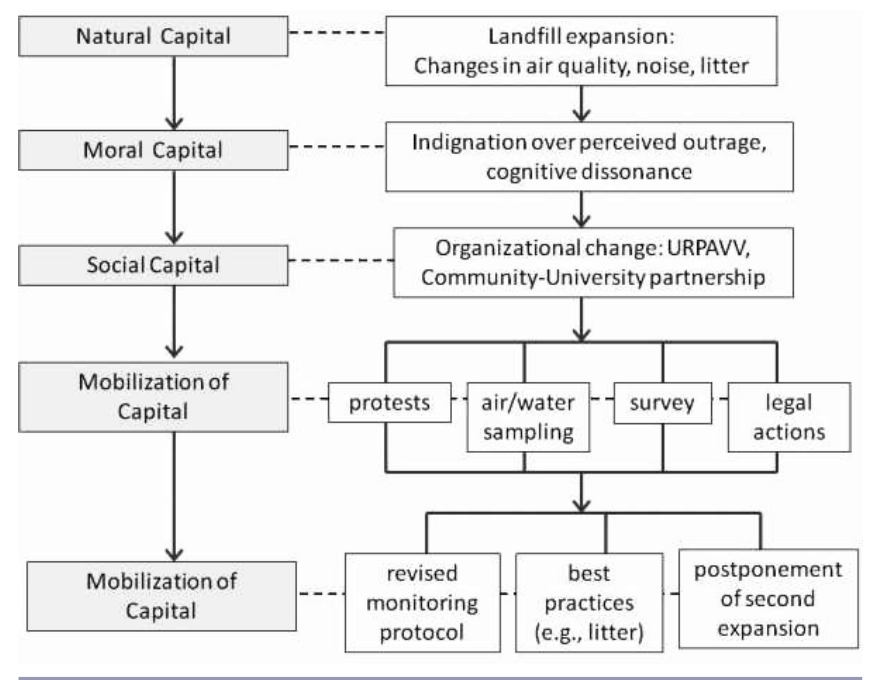

This example demonstrated resilience, in social-ecological terms, in that decrements in physical capital (due to the adverse air quality experienced on a daily basis by community residents) were addressed by existing stocks of social capital. Furthermore, the response also generated new forms of human and social capital. It was the sense of moral injustice among Val Verde residents that was the catalyst to generate these various other kinds of capital. For example, the existing store of social capital in the community was tapped when the landfill expansion led to vigorous efforts at mobilizing the community around environmental issues. As a consequence of this action, new social capital was created, with the eventual creation of a new organization called URPAVV (Union de Residents para la Proteccion Ambiental de Val Verde). URPAVV then created partnerships with university researchers and a legal aid organization. This also led to an increase in human capital, embodied in new skills and practices that community residents took on. With assistance from a professor from California State
University, Los Angeles, URPAVV members learned how to conduct a door-to-door health survey. With assistance from an organization called Communities for a Better Environment, URPAVV members learned how to conduct air sampling. Capturing and describing these capital transactions help us explain changes in the social-ecological system (Fig. 2). This aspect of the research involves detailed descriptions of the social and organizational changes. We can also trace new pathways of legal, civic, and individual action that were enabled by these increases in social capital-this is what Gibson (1977) referred to as affordance (see also Meyer and Rowan (2006) for an application to institutional life). Such new pathways include a community's ability to routinely test environmental conditions around the landfill in real time, which may then enable submission of material evidence in future environmental impact assessments. At the same time, some possible pathways are still not achievable. The analysis should also recognize that, in large part, increments in social capital did not lead to renewed sources of financial support for URPAVV, which still makes prohibitive the option for future independent legal action by the group. Not all forms of capital are completely fungible from one to the other.

In participant-observer mode, the researchers observed how the emergent social capital was mobilized (or spent) in the form of numerous community actions pertaining to the landfill. A community health survey was conducted. Air samples were taken and tested for air toxics. Testimonies were given at County proceedings. Protest actions, including dressing up as skeletons in front of the County Hall during El Dia de los Muertos, leaflets, and etc., were undertaken. The legal team issued written requests for more information about landfill impacts. URPAVV built connections with the regional/national environmental justice community, beginning with workshops sponsored by Liberty Hill, a California nonprofit aimed at supporting grassroots organizations.

This chain of actions led to responses by other parties, notably the County government and the landfill operators. An improved air and water quality monitoring protocol was put in place. The operator initiated additional practices regarding litter control, water application for dust control, and others. Monitoring reports were delivered as requested. Plans for a second expansion of the landfill were shelved as a result of the conjoint action of all these different policy actors, but even more so due to reductions in solid waste from County-wide recycling efforts and economic downturn.

The Val Verde research, thus, yielded rich descriptions of how one mode of capital, beginning with a decrement in the store of natural capital in Val Verde, was transformed into new resources and actions (see Lejano and Stokols (2010)). It is not enough to categorize this as an environmental justice situation. The social-ecological approach requires us to analyze the particulars of this situation, the unique experiences 
of the residents, and the highly contextual manner in which moral resentment is converted into a suite of resources and actions. Because this type of research combines different knowledge bases, it affords participation of the affected residents themselves in cognitive mapping exercises, surveys, and numerous other modes of voicing their experiences of risk and empowerment. We note that this work was done as part of the community members' own desire to understand their situation more deeply and ways to transform this knowledge into action. Analysis of air quality and health outcomes were things identified by the residents. These aspects of research, along with its impacts on policy, exemplify the best tradition of action research in which subjects reflect on their own situation (Lewin 1946). This type of research is highly contextual: both university researchers and residents learn not about environmental injustice as a general concept, but what it specifically means in Val Verde.

Although this community exhibited resilience in socialecological terms, it still faces challenges that might be characterized as institutional impedance where, as in the nonresilient system depicted in Fig. 1, the residents might find their protests, institutional appeals, and self-monitoring to only have a limited influence on the actions of the County and landfill operator. It is uncertain whether URPAVV has the capacity to assemble the resources required for a formal legal challenge to future attempts to expand the landfill. The situation and the activities of URPAVV are in a holding pattern, but one can predict that if and when there arose economic pressure to expand the landfill again, a similar series of events would unfold. A social-ecological portrayal of the situation thus provides a deeper sense of what those positive and negative channels of action-response are in this situation, what the capacities are of the different actors for action, and how this complex community system works to produce the outcomes observed.

These mechanisms, by which one form of capital is effectively (or ineffectively) transformed into other forms, is a working "model" of the complex system. Although a challenge is that actors might deviate from the reasonable, foreseeable plan of action, the social-ecological model enables us to delineate and analyze pathways that lead to resilience or, conversely, increased vulnerability; what new forms of action are afforded, and those that are still impeded. In the Val Verde case, for example, the analysis suggests that although the community has developed new capacities for analysis and environmental monitoring (e.g., health surveys, air quality measurements), there still are no effective institutional pathways by which such evidence can enter directly into the landfill permitting process.

\section{CONCLUSIONS}

To summarize, a social-ecological frame of analysis improves our understanding of the resilience of human-environment systems, and of complex multi-scale, multi-temporal environmental phenomena in multiple ways:
1. By focusing on transactions, especially between the dimensions of physical/natural systems and systems of meaning, we pay close attention to exchange (i.e., response and counter-response) between these systems, and between different sub-systems (e.g., community and regional government).

2. By understanding transaction as a complex of action and knowledge, we remain open to using approaches from action-research and participatory-collaborative learning in transdisciplinary fashion.

3. By so doing, we are able to combine scientific, physicalsystems knowledge with symbolic, experiential, and other types of knowledge.

4. Rather than subsuming sociocultural systems under the frameworks and logics of natural systems research, we remain open to the complex logics of the sociocultural.

In this type of inquiry, human-environment transactions are construed not as static notions of fit nor describable by structural (and determinate) governing equations, but as complex and dynamic processes of adaptation and counteradaptation. Social-ecological research emphasizes the transactions between the natural and semiotic dimensions, whether this is done explicitly (e.g., as transformations between one form of capital and another) or indirectly (e.g., as interacting physical and institutional systems wherein rules developed in the latter affect the former). Future research should more closely investigate the institutional mechanisms that enable or impede transactions between different forms of capital.

We end this review with the hope that resilience scholars might more actively share their epistemological and methodological foundations with each other, thus increasing the transformative potential of our common endeavor.

Responses to this article can be read online at: http://www.ecologyandsociety.org/issues/responses. $\mathrm{php} / 5301$

\section{Acknowledgments:}

The authors would like to thank subject editor Prof. Bruce Goldstein, and two anonymous reviewers for their insightful comments and suggestions.

\section{LITERATURE CITED}

Alihan, M. A. 1938. Social ecology: a critical analysis. Cooper Square Publishers, Inc., New York, New York, USA.

Altman, I., and B. Rogoff. 1987. World views in psychology: trait, interactional, organismic, and transactional perspectives. 
Pages 7-40 in D. Stokols and I. Altman, editors. Handbook of environmental psychology. Wiley, New York, New York, USA.

Anderies, J. M., M. A. Janssen, and E. Ostrom. 2004. A framework to analyze the robustness of social-ecological systems from an institutional perspective. Ecology and Society 9(1): 18. [online] URL: http://www.ecologyandsociety.org/ vol9/iss $1 / \operatorname{art} 18$

Berkes, F., J. Colding, and C. Folke, editors. 2003. Navigating social ecological systems: Building resilience for complexity and change. Cambridge University Press, Cambridge, UK. http://dx.doi.org/10.1017/CBO9780511541957

Berkes, F., and C. Folke, editors. 1998. Linking social and ecological systems: management practices and social mechanisms for building resilience. Cambridge University Press, Cambridge, UK.

Berkowitz, P. 1999. Virtue and the making of modern liberalism. Princeton University Press, Princeton, New Jersey, USA.

Binder, A. 1972. A new context for psychology: social ecology. American Psychologist 27:903-908. http://dx.doi. org/10.1037/h0033434

Bookchin, M. 2005. The ecology of freedom: the emergence and dissolution of hierarchy. AK Press, Oakland, California, USA.

Bourdieu, P. 1977. Outline of a theory of practice. Cambridge University Press, Cambridge, UK.

Bourdieu, P. 1986. The forms of capital. Pages 241-258 in J. G. Richardson, editor. Handbook of theory and research for the sociology of education. Greenwood Press, New York, New York, USA.

Bronfenbrenner, U. 1979. The ecology of human development: experiments by nature and design. Harvard University Press, Cambridge, Massachusetts, USA.

Bronfenbrenner, U. 1992. Ecological systems theory. Pages 187-249 in R. Vasta, editor. Six theories of child development: revised formulations and current issues. Jessica Kingsley Publishers, London, UK.

Brown, V. A. 2010. Collective inquiry and its wicked problems. Pages 61-81 in V. A. Brown, J. A. Harris, and J. Y. Russell, editors. Tackling wicked problems through the transdisciplinary imagination. Earthscan, London, UK.

Bullard, R. D., editor. 2005. The quest for environmental justice: human rights and the politics of pollution. Sierra Club Books, San Francisco, California, USA.

Bullard, R. D., and G. S. Johnson. 2000. Environmental justice: grassroots activism and its impact on public policy decision making. Journal of Social Issues 56:555-578. http:// dx.doi.org/10.1111/0022-4537.00184

Castells, M. 1996. The rise of the network society. Blackwell Publishers, Malden, Massachusetts, USA. http://dx.doi. org/10.1002/9781444319514

Christaller, W. 1933. The central places of southern Germany. Gustav Fischer, Jena, Germany.

Clements, F. 1905. Research methods in ecology. The University of Nebraska Press, Lincoln, Nebraska, USA.

Coleman, J. 1988. Social capital in the creation of human capital. American Journal of Sociology 94: S95-S120. http:// dx.doi.org/http://dx.doi.org/10.1086/228943

Costanza, R., R. d'Arge, R. de Groot, S. Farber, M. Grasso, B. Hannon, K. Limburg, S. Naeem, R. V. O'Neill, J. Paruelo, R. G. Raskin, P. Sutton, and M. van den Belt. 1997. The value of the world's ecosystem services and natural capital. Nature 387:253-260. http://dx.doi.org/10.1038/387253a0

County of Los Angeles. 1992. Draft environmental impact report for expansion of the Chiquita landfill. Department of Regional Planning, Los Angeles, California, USA.

County of Los Angeles. 1996. Final environmental impact report, Chiquita Canyon landfill expansion. Closure and resource recovery facilities. Department of Regional Planning, Los Angeles, California, USA.

Daily, G. C., and P. R. Ehrlich. 1999. Managing earth's ecosystems: an interdisciplinary challenge. Ecosystems 2:277-280. http://dx.doi.org/10.1007/s100219900075

Darwin, C. 1859/1964. The origin of species. London, UK, 1859, first edition. Harvard University Press, Cambridge, Massachusetts, USA.

Emery, F. E., editor. 1969. Systems thinking. Penguin Books, London, UK.

Emery, F. E., and E. L. Trist. 1972. Towards a social ecology: contextual appreciation of the future in the present. Plenum Press, London, UK.

Firey, W. 1945. Sentiment and symbolism as ecological variables. American Sociological Review 10:140-148. http:// dx.doi.org/10.2307/2085629

Folke, C. 2006. Resilience: the emergence of a perspective for social-ecological systems analyses. Global Environmental Change 16:253-267. http://dx.doi.org/10.1016/j. gloenvcha.2006.04.002

Gibson, J.J. 1977. The theory of affordances. Pages 67-82 in R. Shaw and J. Bransford, editors. Perceiving, acting, and knowing: toward an ecological psychology. Erlbaum, Hillsdale, New Jersey, USA. 
Giddens, A. 1984. The constitution of society. University of California Press, Berkeley, California, USA.

González, E. R., R. P. Lejano, G. Vidales, R. Conner, Y. Kidokoro, B. Fazeli, and R. Cabrales. 2007. Participatory action research for environmental health: encountering Freire in the urban barrio. Journal of Urban Affairs 29(1):79-102. http://dx.doi.org/10.1111/j.1467-9906.2007.00324.x

Gunderson, L., and C. Folke. 2011. Resilience 2011: leading transformational change. Ecology and Society 16(2): 30. [online] URL: http://www.ecologyandsociety.org/voll6/iss2/ $\underline{\operatorname{art} 30 /}$

Gunderson, L., and C. S. Holling. 2002. Panarchy: understanding transformations in human and natural systems. Island Press, Washington, D.C., USA.

Haeckel, E., and E. R. Lankaster. 1876. The history of creation. H. S. King and Co., London, UK.

Haig, R. M. 1926. Toward an understanding of the metropolis. Quarterly Journal of Economics 40:402-434. http://dx.doi. org/10.2307/1885172

Hawken, P., A. Lovins, and H. Lovins. 1999. Natural capitalism: creating the next industrial revolution. Little, Brown and Co., New York, New York, USA.

Hawley, A. 1950. Human ecology: a theory of community structure. The Ronald Press Company, New York, New York, USA.

Hipp, J. R., R. W. Faris, and A. Boessen. 2011. Measuring 'neighborhood': constructing network neighborhoods. Social Networks 34(1):128-140. http://dx.doi.org/10.1097/00008526-199603000-00009

Husserl, E. 1900. Logical investigations. Volume 1. Logische Untersuchungen. Routledge, New York, New York, USA.

Kane, J. 2001. The politics of moral capital. Cambridge University Press, Cambridge, UK. http://dx.doi.org/http://dx. doi.org/10.1017/CBO9780511490279

Katz, D., and R. L. Kahn. 1966. The social psychology of organizations. Wiley, New York, New York, USA. http://dx. doi.org/10.1111/j.1464-0597.1986.tb01271.x

Latour, B. 2005. Reassembling the social: an introduction to actor-network theory. Oxford University Press, Oxford, UK.

Lejano, R., M. Ingram, and H. Ingram. 2013. The power of narrative in environmental networks. MIT Press, Cambridge, Massachusetts.

Lejano, R., and C. Leong. 2012. A hermeneutic approach to explaining and understanding public controversies. JPART Journal of Public Administration Research and Theory 22 (4):793-814. http://dx.doi.org/10.1093/jopart/mus001
Lejano, R., and D. Stokols. 2010. Understanding minority residents' perceptions of neighborhood risks and environmental justice: new modalities, findings, and policy implications. Journal of Architectural and Planning Research 27:107-123.

Lewin, K. 1946. Action research and minority problems. Journal of Social Issues 2:34-36. http://dx.doi.org/10.1111/ j.1540-4560.1946.tb02295.x

Maruyama, M. 1963. The second cybernetics: deviationamplifying mutual causal processes. American Scientist 51:164-179.

Marx, K. 1930. Das kapital. J. M. Dent and Sons, Ltd., London, UK.

Meyer, H.-D., and B. Rowan. 2006. Institutional analysis and the study of education. Pages 1-14 in H.-D. Meyer and B. Rowan, editors. The new institutionalism in education. State University of New York Press, Albany, New York, USA.

Michelson, W. 1970. Man and his urban environment: a sociological approach. Addison-Wesley, Reading, Massachusetts, USA.

Miller, D. W. 1999. Perhaps we bowl alone, but does it really matter? Selected books on civil society and virtue.The Chronicle of Higher Education: A16; 16 July 1999. [online] URL: http://chronicle.com/article/Perhaps-We-Bowl-Alonebut/9562

Moos, R. H. 1979. Social ecological perspectives on health. Pages 523-547 in G. C. Stone, F. Cohen, and N. E. Adler, editors. Health psychology: a handbook. Jossey Bass, San Francisco, California, USA.

Neumayer, E. 1999. Global warming: discounting is not the issue, but substitutability is. Energy Policy 27:33-43. http:// dx.doi.org/10.1016/S0301-4215(98)00063-9

Ogunseitan, O. A. 2005. Topophilia and the quality of life. Environmental Health Perspectives 113(2):143-148. http:// dx.doi.org/10.1289/ehp.7467

Ostrom, E. 2009. A general framework for analyzing sustainability of social ecological systems. Science 325:419422. http://dx.doi.org/10.1126/science.1172133

Park, R., E. Burgess, and R. D. McKenzie, editors. 1925. The city. University of Chicago Press, Chicago, Illinois, USA.

Peterson, G. 2010. Expansion of social ecological systems science. Reslilence Science: 16 April 2010. [online] URL: http://rs.resalliance.org/2010/04/16/expansion-of-social ecologicalsystems-science/

Putnam, R. D. 2000. Bowling alone: the collapse and revival of American community. Simon and Schuster, New York, New York, USA. http://dx.doi.org/10.1145/358916.361990 
Redman, C. L. 1999. Human dimensions of ecosystem studies. Ecosystems 2:296-298. http://dx.doi.org/10.1007/s100219900079

Redman, C. L., J. M. Grove, and L. H. Kuby. 2004. Integrating social science into the long-term ecological research (LTER) network: social dimensions of ecological change and ecological dimensions of social change. Ecosystems 7(2):161171. http://dx.doi.org/10.1007/s10021-003-0215-Z

Rosenblum, N.L. 1998. Membership and morals: the personal uses of pluralism. Princeton University Press, Princeton, New Jersey, USA.

Schoon, M., C. Fabricus, J. M. Anderies, and M. Nelson. 2011. Synthesis: vulnerability, traps, and trransformations-longterm perspectives from archaeology. Ecology and Society 16 (2): 24. [online] URL: http://www.ecologyandsociety.org/ vol16/iss $2 / \operatorname{art} 24 /$

Sherif, M. 1958. Superordinate goals in the reduction of intergroup conflicts. American Journal of Sociology 63:349356. http://dx.doi.org/10.1086/222258

Smith, M. D., J. Zhang, and F. C. Coleman. 2008. Econometric modeling of fisheries with complex life histories: avoiding biological management failures. Journal of Environmental Economics and Management 55:265-280. http://dx.doi. org/10.1016/j.jeem.2007.11.003

Stokols, D. 1978. Environmental psychology. Pages 253-295 in M. R. Rosenzweig and L. W. Porter, editors. Annual Review of Psychology. Annual Reviews, Palo Alto, California, USA.

Stokols, D. 1992. Establishing and maintaining healthy environments: toward a social ecology of health promotion. American Psychologist 47:6-22. http://dx.doi. org/10.1037/0003-066X.47.1.6

Stokols, D. 1996. Translating social ecological theory into guidelines for community health promotion. American Journal of Health Promotion 10:282-298. http://dx.doi. org/10.4278/0890-1171-10.4.282

Stokols, D. 2006. Toward a science of transdisciplinary action research. American Journal of Community Psychology 38:6377. http://dx.doi.org/10.1007/s10464-006-9060-5

Stokols, D., J. G. Grzywacz, S. McMahan, and K. Phillips. 2003. Increasing the health promotive capacity of human environments. American Journal of Health Promotion 18:413. http://dx.doi.org/10.4278/0890-1171-18.1.4

Stokols, D., S. Misra, M. G. Runnerstrom, and J. A. Hipp. 2009. Psychology in an age of ecological crisis: from personal angst to collective action. American Psychologist 64:181-193. http://dx.doi.org/10.1037/a0014717
Sweet, K. 2011, August 12. Computers rule Wall Street. CNNMoney: 12 August 2011. [online] URL: http://money. cnn.com/2011/08/12/markets/high frequency trading/index. $\underline{\mathrm{htm}}$

Tidball, K., and M. Krasny. 2012. Greening in the red zone: disaster, resilience and community greening. Springer, New York, New York, USA.

von Bertalanffy, L. 1950. The theory of open systems in physics and biology. Science 3:23-29. http://dx.doi.org/http:// dx.doi.org/10.1126/science.111.2872.23

Walker, B., C. S. Holling, S. R. Carpenter, and A. Kinzig. 2004. Resilience, adapatability and transformability in socialecological systems. Ecology and Society 9(2): 5. [online] URL: http://www.ecologyandsociety.org/vol9/iss2/art5/ 